Pedagogy and Psychology of Sport, Vol. 2 / No 1, 2016

Kitowska W., p.10-19

Received: 21.12.2015. Revised 25.12.2015. Accepted: 09.01.2016.

DOI:http://dx.doi.org/10.12775/PPS.2016.002

Original Text published (c) The Author (s) 2016.

Kitowska Wioleta. Ocena rozpowszechnienia dolegliwości reumatycznych wśród osób w przedziale wiekowym 18 -25 lat $=$ Assessment of the prevalence of rheumatic ailments among people aged 18 -25 years. Journal of Education, Health and Sport. 2016;6(1):17-26. eISSN 2391-8306. DOI

http://dx.doi.org/10.5281/zenodo.44536

http://ojs.ukw.edu.pl/index.php/johs/article/view/44536

\title{
Assessment of the prevalence of rheumatic ailments among people aged 18-25 years
}

\section{Ocena rozpowszechnienia dolegliwości reumatycznych wśród osób w przedziale wiekowym 18-25 lat}

\author{
Wioleta Kitowska \\ Studenckie Koło Naukowe Zdrowia Publicznego, Sekcja Promocja Zdrowia, \\ Warszawski Uniwersytet Medyczny \\ Opiekun: dr n. med. Dominik Olejniczak, mgr Joanna Skonieczna
}

Keywords: rheumatic diseases, epidemiology, young adults

Slowa kluczowe: choroby reumatyczne, epidemiologia, młodzi, dorośli

\begin{abstract}
Introduction: Rheumatic diseases, along with other diseases of the musculoskeletal system are among the most common chronic diseases in the world. Factors predisposing to rheumatic diseases are genetic factors, external physical factors as well as the so-called "civilization factor" - an effect of modern "civilized" life. It is suspected that rheumatic diseases are responsible for absorbing the largest portion of the GDP of all diseases.

Materials and Method: The study was conducted using a diagnostic survey. The study population consisted of university students in the age group of 18-25 years. The tool used to perform the test was an original questionnaire, which was distributed using the CAWI technique. The number of respondents amounted to 308 persons.

Results: As many as $38 \%$ of respondents declared visiting a doctor due to ailments of the skeletal system, which were not a result of injury. A larger proportion of women $(40 \%)$ than men $(30 \%)$ declared such visits. Most people do not have bone or joint deformities that are not caused by injury (59\%). More women (31\%) than men $(29 \%)$ acknowledged an existence of such defects. More than half of both women $(50 \%)$ and men $(52 \%)$ have experienced joint stiffness or difficulty moving said joints.

Conclusion: Young adults often show symptoms that may be associated with rheumatic diseases. However, only a small percentage have seen a medical professional because of them, and even less have done tests aimed at diagnosing a rheumatic disease. The low rate may be due to lack of knowledge about rheumatic diseases. It is possible, that more people live to fall ill at an earlier age.
\end{abstract}




\section{Streszczenie}

Wprowadzenie: Choroby reumatyczne, wraz z innymi chorobami układu kostno-mięśniowego są jednymi z najpowszechniejszych schorzeń chronicznych na świecie. Czynniki usposabiające do chorób reumatycznych to czynniki genetyczne, zewnętrzne czynniki fizyczne oraz tzw. czynnik cywilizacyjny - efekt współczesnego „cywilizowanego” życia. Podejrzewa się, że choroby reumatyczne są odpowiedzialne za pochłanianie największego odsetka PKB ze wszystkich chorób.

Materiał i metoda: Badanie zostało przeprowadzone metodą sondażu diagnostycznego. Populację badaną stanowili studenci uczelni wyższych w przedziale wiekowym 18-25 lat. Narzędziem zastosowanym do przeprowadzenia badania był autorski kwestionariusz, który był rozprowadzony techniką typu CAWI. Ilość respondentów łącznie wynosiła 308 osób.

Wyniki: Aż 38\% osób deklarowało obecność na wizycie lekarskiej z powodu dolegliwości ze strony układu kostno-stawowego, które nie były wynikiem kontuzji. Większy odsetek kobiet (40\%) niż mężczyzn (30\%) bywało u lekarza. U większości osób nie występuj zniekształcenia kości lub stawów, które nie są spowodowane urazem (59\%). Więcej kobiet (31\%) niż mężczyzn (29\%) deklarowało istniejące zniekształcenia. Ponad połowa zarówno kobiet $(50 \%)$ jak i mężczyzn (52\%) doświadczyła w przeszłości poczucia sztywności stawu lub trudności w jego poruszaniu.

Wnioski: U tzw. młodych dorosłych (ang. young adults) często występują objawy, które mogą być powiązane z chorobą reumatyczną. Mały odsetek osób jednak idzie z tego powodu do lekarza, a jeszcze mniejszy bada się w kierunku rozpoznania choroby reumatycznej. Niska frekwencja może wynikać z braku wiedzy na temat chorób reumatycznych. Możliwe jest to, że więcej osób dożywa, żeby zachorować w młodszym wieku.

\section{Wprowadzenie}

Choroby przewlekłe stają się powszechnym problemem współczesnego świata. Stwarzają poważne wyzwanie dla systemów ochrony zdrowia i dla państw. Spośród nich, duże obciążenie pod kątem zdrowotnym i ekonomicznym stanowią choroby reumatyczne.

Definicja choroby przewlekłej według Komisji Chorób Przewlekłych przy Światowej Organizacji Zdrowia to „wszelkie zaburzenia lub odchylenia od normy, które mają jedną lub więcej $\mathrm{z}$ następujących cech charakterystycznych: są trwałe, pozostawiają po sobie inwalidztwo, spowodowane są nieodwracalnymi zmianami albo wg wszelkich oczekiwań wymagać będą długiego okresu nadzoru, obserwacji czy opieki’.[1]

Do chorób przewlekłych zalicza się między innymi choroby reumatyczne. Choroby reumatyczne to zespół dolegliwości dotykających organizm ludzki w różnorodny sposób. Ogólna definicja choroby reumatycznej to: zaburzenia organizmu, które głównie powodują obrzęk, stan zapalny i ból w stawach i mięśniach. Każdy staw może być dotknięty przez takie zaburzenie. Istnieje ponad 100 chorób reumatycznych. Przebiegają u ludzi w różnych stopniach ciężkości i uciążliwości. Rzadko są bezpośrednią przyczyną zgonu, lecz mogą prowadzić do poważnych niepełnosprawności. Do niedawna patogeneza tych schorzeń była w dużej mierze nieznana. Badania $\mathrm{z}$ ostatniego dziesięciolecia pozwalają stwierdzić, że podłoże tych chorób leży w systemie autoimmunologicznym organizmu. Nie istnieje żaden drobnoustrój powodujący objawy występujące w chorobach reumatycznych. Jest to proces spowodowany wyłącznie zaburzeniami ustrojowymi. Dalsze badania są kierowane w stronę immunologii i systemu odpornościowego. Nowe terapie lekowe analogicznie są kierowane w tą stronę, lecz sam mechanizm działania i przez to sposób walczenia z tymi chorobami jest jeszcze nie do końca jasny.[2] 
Choroby reumatyczne i inne kondycje układu kostno-mięśniowego są podejrzewane o bycie najpowszechniejszymi schorzeniami chronicznymi na świecie. Czynniki usposabiające do chorób reumatycznych to czynniki genetyczne, zewnętrzne czynniki fizyczne oraz tzw. czynnik cywilizacyjny - efekt współczesnego „cywilizowanego” życia. Podejrzewa się, że choroby reumatyczne są odpowiedzialne za pochłanianie największego odsetka PKB ze wszystkich chorób.

Chorych reumatycznie często utożsamia się $\mathrm{z}$ populacją $\mathrm{W}$ podeszłym wieku. Nie wszyscy są świadomi, że choroby reumatyczne mogą dotyczyć każdego niezależnie od wieku. Wraz z zwiększającą się ilością chorych, zwiększa się też odsetek młodych osób cierpiących na schorzenia reumatycznie. Młodzi ludzie będą szczególnie dotknięci taką chorobą, która ogranicza ich mobilność, perspektywy pracy, oraz wszelki rozwój osobisty.

\section{Material i metoda}

Badanie zostało przeprowadzone metodą sondażu diagnostycznego. Populację badaną stanowili studenci uczelni wyższych w przedziale wiekowym 18-25 lat. Badanie miało charakter obserwacyjny, a sposobem doboru próby był dobór okolicznościowy. Narzędziem zastosowanym do przeprowadzenia badania był autorski kwestionariusz, który był rozprowadzony techniką typu CAWI (Computer-Assisted Web Interview). Zbieranie odpowiedzi rozpoczęto 22 kwietnia 2015 roku i zakończono 7 maja 2015 roku. Ilość respondentów łącznie wynosiła 308 osób. Odrzucono 11 ankiet ze względu na brak kompletności odpowiedzi. Po weryfikacji zostały zaakceptowane ankiety 297 respondentów, w tym 234 kobiet i 63 mężczyzn.

\section{Wyniki}

Zdecydowana większość zarówno kobiet (59\%) jak i mężczyzn (54\%) ocenia swój stan zdrowia jako dobry. Mały odsetek osób deklarował zły (1\%) lub bardzo zły (0\%) stan zdrowia. Aż 38\% osób deklarowało obecność na wizycie lekarskiej z powodu dolegliwości ze strony układu kostno-stawowego, które nie były wynikiem kontuzji. Większy odsetek kobiet (40\%) niż mężczyzn (30\%) bywało u lekarza.

Jest widoczna różnica $\mathrm{w}$ zakresie poczucia ogólnego osłabienia lub zmęczenia nie związanego z ilością snu pomiędzy grupą kobiet i mężczyzn. Kobiety częściej deklarowały obniżone samopoczucie (49\%) niż mężczyźni, którzy częściej odpowiadali, że nie odczuwają ogólnego osłabienia lub zmęczenia (56\%).

U większości osób nie występują zniekształcenia kości lub stawów, które nie są spowodowane urazem (59\%). Więcej kobiet (31\%) niż mężczyzn (29\%) deklarowało istniejące zniekształcenia.16\% osób w przedziale wiekowym 18-25 lat miało w przeszłości 
obrzęk stawów nie spowodowany kontuzją. Obrzęk częściej występował u kobiet (18\%) niż u mężczyzn (6\%).

Jedno z pytań dotyczyło występowania małych guzków pod powierzchnią skóry oraz nad powierzchnią stawów. To pytanie miało na celu sprawdzenie częstotliwości występowania potencjalnych guzków reumatoidalnych u ludzi. Większość osób (85\%) nie deklarowało obecności guzków. 5\% osób deklarowało, że ma takie guzki, a 10\% nie jest pewna.

Ponad połowa zarówno kobiet (50\%) jak i mężczyzn (52\%) doświadczyła w przeszłości poczucia sztywności stawu lub trudności w jego poruszaniu. $67 \%$ badanej populacji doświadczyło w przeszłości bólu stawu, mięśni i/lub kości, który był co najmniej trudny do zniesienia.

Mężczyźni częściej niż kobiety wskazywali, że takiego bólu do tej pory nie doświadczyli. $\mathrm{Z}$ osób, które deklarowały doświadczenie takiego bólu w przeszłości, 50\% badanych oświadczyło, że ból trwał dłużej niż trzy dni. Zjawisko to występowało częściej u mężczyzn (60\%) niż u kobiet (48\%). Ból co najmniej trudny do zniesienia oraz powtarzający się, czyli okresowo występujący w tym samym miejscu, występował u 65\% osób. Odsetek kobiet wskazujący taką sytuację był o 19\% większy niż u mężczyzn. Z osób, które doświadczyły w przeszłości ból trudny do zniesienia, 70\% (78\% mężczyzn i 67\% kobiet) powiedziało, że był to między innymi ból stawu/stawów. Co piąta osoba spośród grupy, która doświadczyła w przeszłości ból stawu/stawów, zaznała ponadto ból przenoszący się z jednego stawu do drugiego. Kobiety prawie cztery razy częściej (38\%) niż mężczyźni (10\%) oświadczały, że doznały symetrycznego bólu stawów nie będącego wynikiem urazu lub wysiłku fizycznego.

$\mathrm{Na}$ pytanie o treści „Jakie stawy bolały? (wielokrotny wybór)” otrzymano poniższe rozkłady odpowiedzi (Wykres nr 1, wykres nr 2):

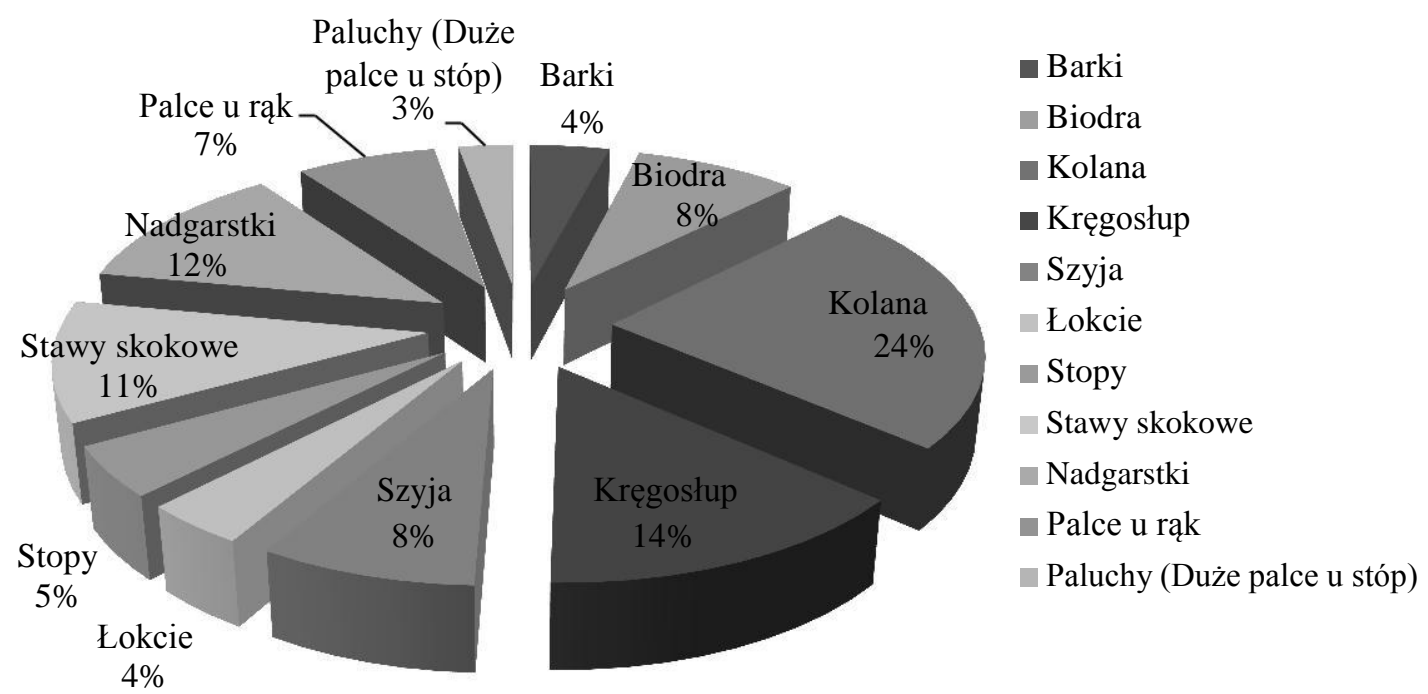

Wykres nr 1. Rozkład bólu stawów ze względu na umiejscowienie $(\mathrm{N}=138)$. 
Najczęstsze umiejscowienie bólu stawów to stawy kolanowe (67\%), kręgosłup (40\%) oraz nadgarstki (34\%).

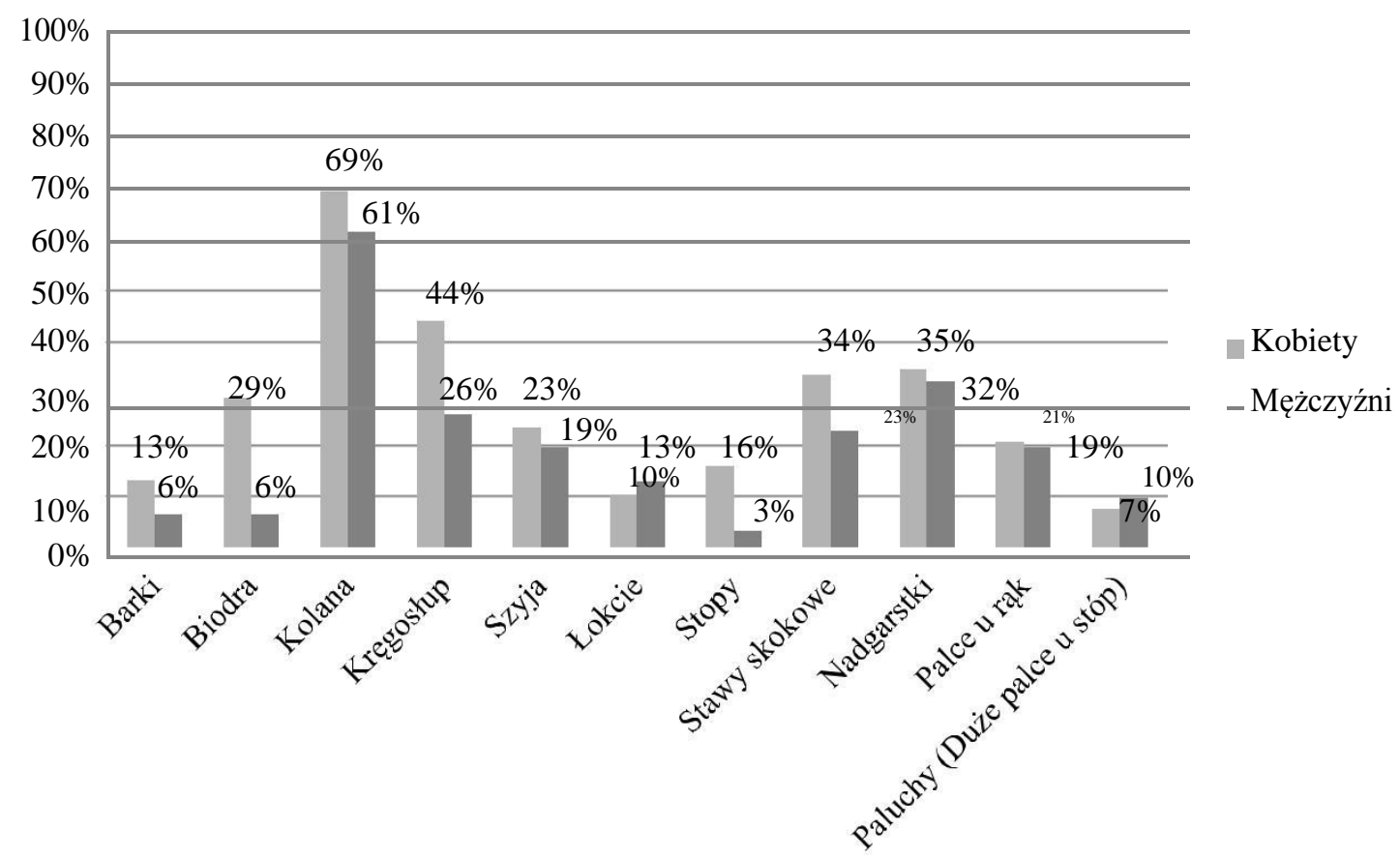

Wykres nr 2. Umiejscowienie występowania bólu stawu/stawów wg płci $(\mathrm{N}=138)$.

Kobiety (69\%) częściej niż mężczyźni (61\%) doznawały bólu stawów kolanowych. Drugie i trzecie miejsce u kobiet zajmują bóle kręgosłupa (44\%) i nadgarstki (35\%). U mężczyzn odpowiednio nadgarstki (32\%) i kręgosłup (26\%).

Na pytanie o treści „Według tej skali, jak oceniasz swój ból (skala od 0 do 10, gdzie 0 to brak bólu, a 10 to najsilniejszy wyobrażalny ból)?" otrzymano poniższe rozkłady odpowiedzi (Wykres nr 3, wykres nr 4):

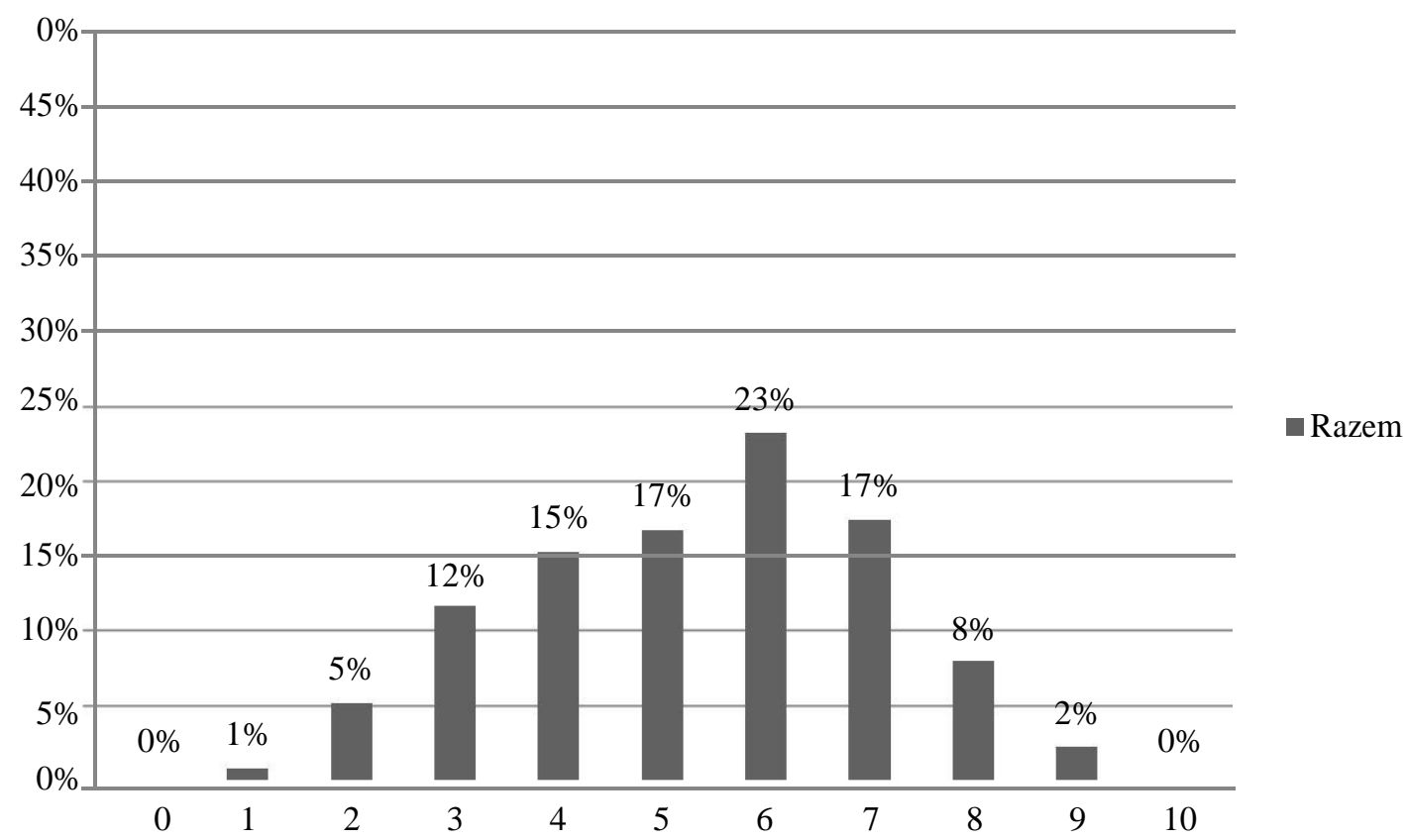

Wykres nr 3. Ocena bólu wg skali 0 (brak bólu) - 10 (najsilniejszy wyobrażalny ból) $(\mathrm{N}=138)$. 
Gdy pytano o siłę bólu, najczęściej zaznaczano odpowiedź „6” (23\%). 0\% osób wskazało odpowiedzi „,0 - brak bólu” oraz „10 - najsilniejszy wyobrażalny ból”.

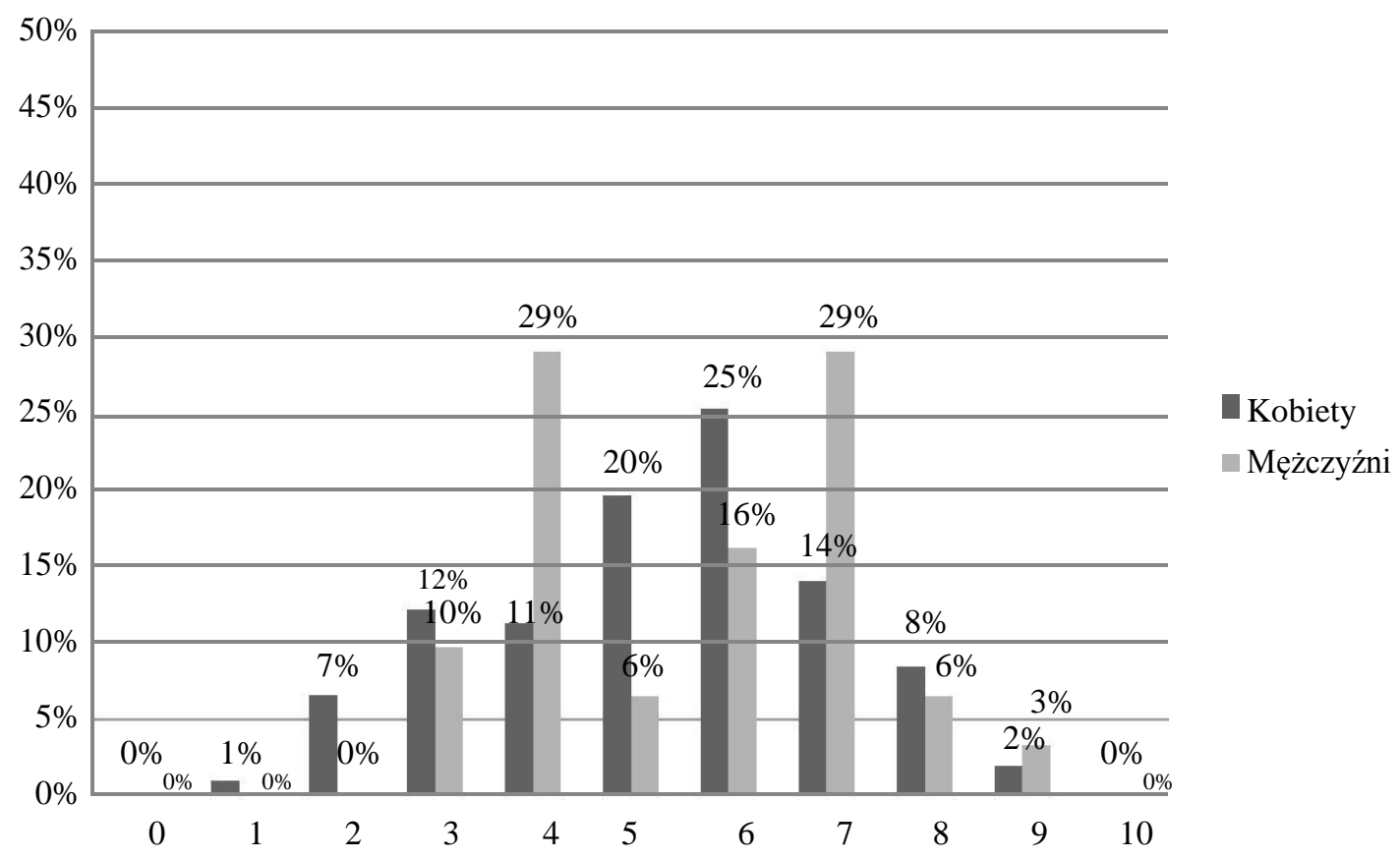

Wykres nr 4. Ocena bólu wg płci, wg skali 0 (brak bólu) - 10 (najsilniejszy wyobrażalny ból) $(\mathrm{N}=138)$.

Kobiety najczęściej wskazywały wartość ' 6 ' (25\% kobiet), natomiast najwięcej mężczyzn wskazało w równej mierze wartości '4' i '7' (w obu przypadkach 29\%). Ponad 1/3 respondentów (37\%) deklarowało, że doświadczyło kiedykolwiek poczucia sztywności, trudności w poruszaniu lub bólu jakiegoś stawu po obudzeniu się rano, które ustąpiło

po „rozruszaniu się”. Co czwarta osoba doświadczyła w przeszłości bólu stawu, kości i/lub mięśni (nie spowodowany urazem), który obudził tą osobę w nocy. Nie był to ból spowodowany urazem. 27\% kobiet i 21\% mężczyzn zaznaczyło taką odpowiedź.

Niewielki odsetek ankietowanych (10\%) miał kiedykolwiek robione badania w kierunku rozpoznania choroby reumatycznej. Zdecydowana większość osób deklarowała brak występowania u nich zespołu cieśni nadgarstka (RSI). Znikomy odsetek kobiet zadeklarowało, że ma to schorzenie (2\%), natomiast żaden mężczyzna nie zgłosił występowania tej choroby.

Natomiast, na pytanie o treści „Czy występował kiedykolwiek u Ciebie jeden $\mathrm{z}$ następujących objawów: mrowienie w nadgarstku; osłabienie chwytu; brak precyzji w ruchach rąk; ograniczenie ruchów rąk/nadgarstków; wypadanie trzymanych przedmiotów

z ręki; trudność w zaciśnięciu ręki w pięść?" otrzymano poniższe rozkłady odpowiedzi (Wykres nr 5, wykres nr 6): 


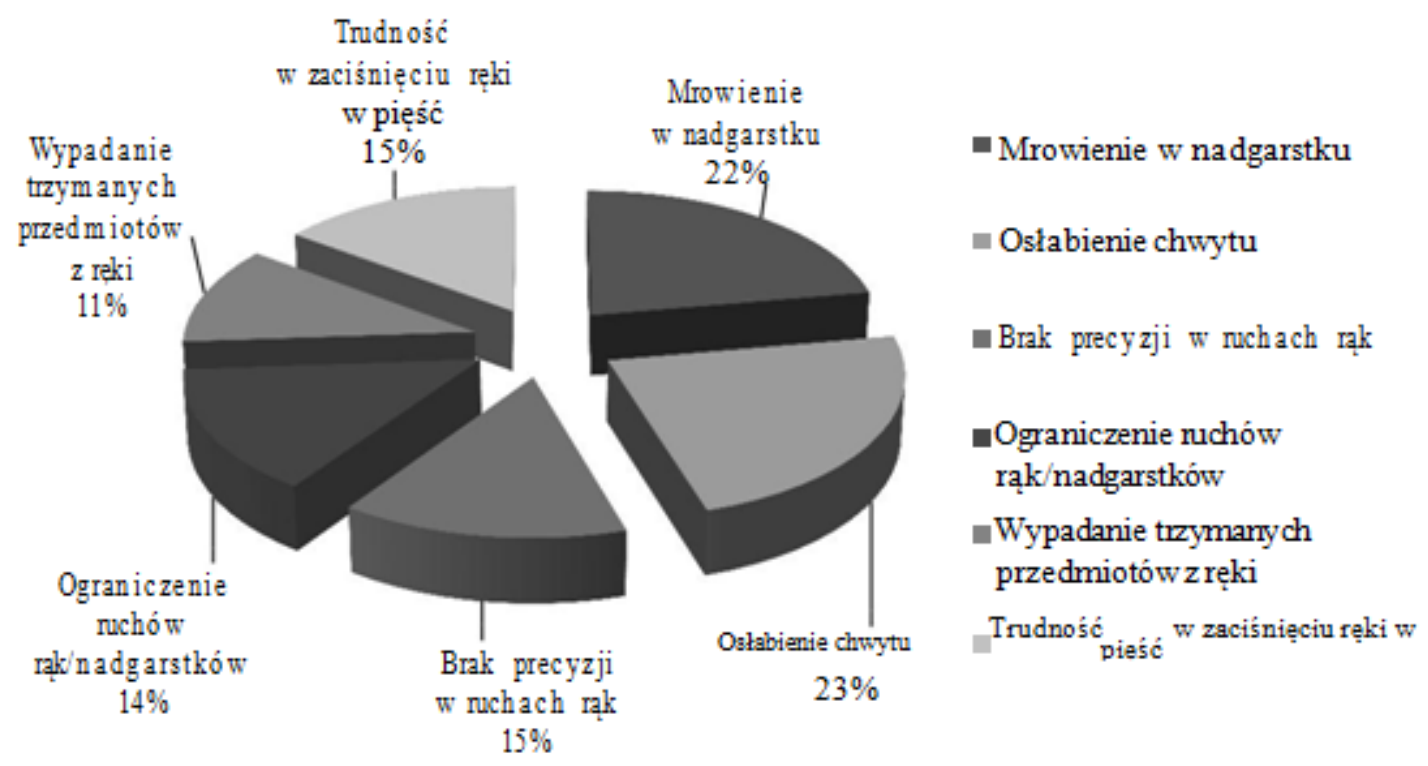

Wykres nr 5. Rozkład objawów zespołu cieśni nadgarstka $(\mathrm{N}=297)$.

Najczęściej występującymi objawami zespołu cieśni nadgarstka są osłabienie chwytu $(23 \%)$ i mrowienie w nadgarstku $(22 \%)$.

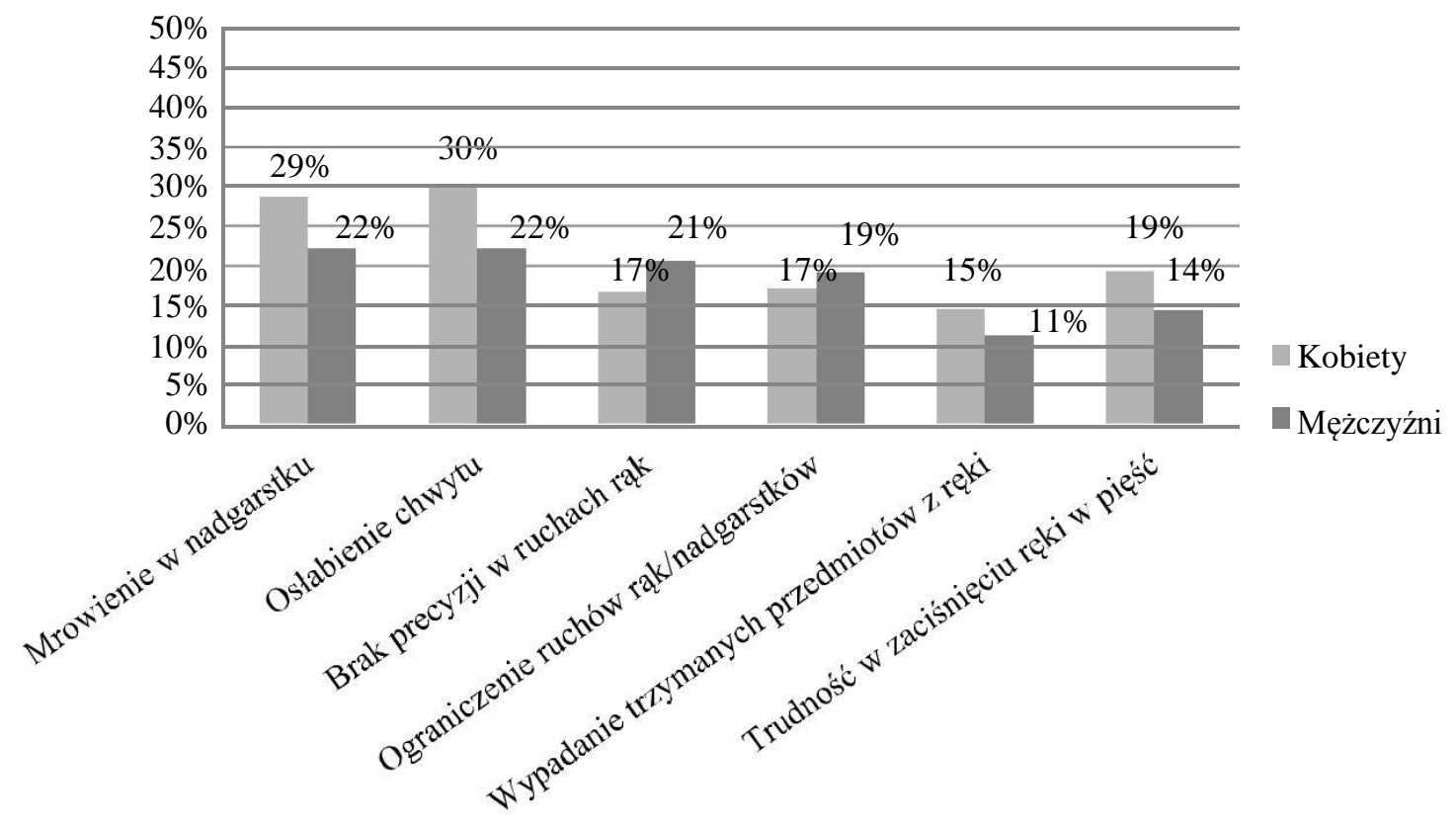

Wykres nr 6. Występowanie objawów związanych z zespołem cieśni nadgarstka wg płci $(\mathrm{N}=297)$.

Kobiety częściej niż mężczyźni doświadczają następujących objawów: osłabienie chwytu (30\%); mrowienie w nadgarstku (29\%); trudność w zaciśnięciu ręki w pięść (19\%); wypadanie trzymanych przedmiotów z ręki (15\%). Mężczyźni częściej niż kobiety 
doznają braku precyzji w ruchach rąk (21\%) oraz ograniczenia ruchów rąk/nadgarstków $(19 \%)$.

63\% respondentów przyznało, że ktoś u nich w rodzinie cierpi lub cierpiał na dolegliwości ze strony układu kostno-stawowego. Z 297 respondentów, 28\% uczęszczało do lekarza z powodu bólu lub sztywności stawu, mięśni i/lub kości (nie będące wynikiem urazu lub wysiłku fizycznego). Kobiety około dwa razy częściej chodziły do lekarza. 42\% respondentów zaznaczyło, że występował u nich co najmniej jeden objaw schorzenia reumatycznego (ból, ograniczenie sprawności lub obrzęk stawów). $\mathrm{Z}$ tych $42 \%$, najczęściej występującym objawem schorzenia reumatycznego to ból (61\%). W mniejszym stopniu występuje ograniczenie sprawności (25\%) i obrzęk stawów (14\%). $26 \%$ kobiet i 37\% mężczyzn odpowiedziało, że mieli kogoś w rodzinie, kto leczy lub leczył się na chorobę reumatyczną.

$\mathrm{Na}$ pytanie o treści „Proszę zaznaczyć kto w rodzinie leczy/leczył się na chorobę reumatyczną (wielokrotny wybór)” najczęściej spokrewniona osoba, która leczy/leczyła się na chorobę reumatyczną to babcia $(54,12 \%)$. Na drugim miejscu jest matka $(35,29 \%)$.

\section{Dyskusja}

Kwestia chorób reumatycznych obecnych w społeczeństwie, a szczególnie wśród osób młodych, jest niezwykle istotna. Choroby reumatyczne będą się stawały coraz bardziej powszechne chociażby z tego powodu, że ludzi na świecie jest coraz więcej. Młodych ludzi szczególnie jest więcej niż kiedyś - jeszcze 60 lat temu współczynnik zgonów niemowląt na 1000 urodzeń wynosił ponad 100. Do 2014 r. współczynnik zmalał do 4,2 zgonów na 1000 urodzeń $[3,4]$.

Według Światowej Organizacji Zdrowia, bóle kręgosłupa są najczęstszym powodem niepełnosprawności pośród „młodych dorosłych”. W badaniu własnym, gdy zapytano o umiejscowienie bólu, najczęściej jednak wskazywano kolana $(63,39 \%)$ [5].

Badanie „Nasze zdrowie, nasze dolegliwości” przeprowadzone przez Instytut Reumatologii oraz NIZP wskazuję, że 1/3 populacji badanej nigdy nie była u lekarza z powodu swoich dolegliwości reumatycznych. W badaniu własnym, spośród 297 osób, 124 (41,75\%) oznajmiło, że występuje u nich co najmniej jeden z objawów choroby reumatycznej: ból stawów, obrzęk stawów, ograniczenie sprawności, co druga osoba $(50,8 \%)$ spośród zgłaszających objawy nie była u lekarza z powodu tych dolegliwości [6].

W artykule z 2003 r. autorstwa Anthony D. Woolf i Bruce Pfelger pt. „Burden of major musculoskeletal conditions" zanotowano, że około 30\% dorosłej populacji Stanów Zjednoczonych jest dotknięta bólem stawów, obrzękami lub ograniczeniami w zakresie ruchu. Dla porównania, z badania autorskiego wynika, że takimi dolegliwościami cechuje się 41,75\% respondentów [7]. 
Proces symetrycznego zajmowania stawów przez zapalenie i konsekwentnego bólu dotkniętych miejsc, jest charakterystycznym objawem reumatoidalnego zapalenia stawów. Źródła podają, że kobiety dwa lub trzy razy częściej są dotknięte tym schorzeniem. Badanie własne wykazało jednak, że kobiety aż cztery razy więcej niż mężczyźni doznają bólu symetrycznego $[7,8,9]$.

„EUMUSC” to badanie przeprowadzone w Unii Europejskiej dotyczące chorób układu mięśniowo-szkieletowego. Według raportu z badania pt. „Musculoskeletal Health in Europe", w 2007 roku 22\% Europejczyków miało chroniczne problemy mięśniowe, kostne i stawowe. W badaniu własnym, pytano o ból trwający dłużej niż trzy dni i nie będący wynikiem urazu lub kontuzji. Częstość występowania takiego bólu wynosiła $22,22 \%[10]$.

Według pracy naukowej autorstwa Owczarek i wsp., częstość występowania ogólnie chorób reumatycznych $\mathrm{w}$ populacji wynosi około 4-5\%. Wyniki badania własnego mieszczą się $\mathrm{w}$ tym zakresie i wykazują, że potwierdzoną przez lekarza chorobę reumatyczną ma 4,04\% respondentów [11].

Eumusc.net gromadzi dane $\mathrm{z}$ krajów Unii Europejskiej na temat chorób reumatycznych. Z informacji podanych dla Polski z 2011 r. wynika, że 0,6\% populacji ma klinicznie potwierdzone reumatoidalne zapalenie stawów. Z badania własnego wynika, że odsetek osób z reumatoidalnym zapaleniem stawów potwierdzonym przez lekarza wynosi $1,35 \%[12]$.

\section{Wnioski}

1. U tzw. młodych dorosłych (ang. young adults) często występują objawy, które mogą być powiązane z chorobą reumatyczną. Mały odsetek osób jednak idzie z tego powodu do lekarza, a jeszcze mniejszy bada się w kierunku rozpoznania choroby reumatycznej. Niska frekwencja może wynikać z braku wiedzy na temat chorób reumatycznych.

2. W badaniu niewiele osób oznajmiło, że cierpi na zespół cieśni nadgarstka (patrz Wykres nr 23). W porównaniu, więcej osób zaznaczyło co najmniej jeden z objawów zespołu cieśni nadgarstka (Wykres nr 24). Wyniki mogą świadczyć o niezdiagnozowanych przypadkach RSI oraz innych chorób reumatycznych.

3. Odsetek osób deklarujących zmęczenie lub osłabienie jest dosyć wysoki. Ogólne poczucie osłabienia i zmęczenia to jeden $\mathrm{z}$ potencjalnych objawów choroby reumatycznej. Zmęczenie może być powodowane chorobą jeśli objawia się ona bólem lub sztywnością układu ruchu i przeszkadza w osiągnięciu lub utrzymaniu głębokiego snu. 
4. Kobiety żyją dłużej niż mężczyźni i częściej dożywają wieku, w którym choroby reumatyczne są bardzo powszechne.

5. Wywiad obciążony $\mathrm{w}$ kierunku chorób reumatycznych jest czynnikiem podwyższonego ryzyka ich wystąpienia

\section{Literatura}

1. Kucharczyk I. Zdrowie a przystosowanie społeczne dzieci chorych przewlekle.An nales Universitatis Mariae Curie-Skłodowska Lublin - Polonia, 2005, Vol. LX, Suppl. XVI, str. 1.

2. Meštrović T. News-Medical.net. http://www.news-medical.net/health/What-isRheumatology.aspx (dostęp: 2015.06.30).

3. eGospodarka.pl.http://www.egospodarka.pl/76521,Rozwoj-demograficzny-Polski2011,5,39,1.html (dostęp: 2015.07.27).

4. Bank Danych Lokalnych. Główny Urząd Statystyczny. http://stat.gov.pl/bdl/app/strona.html?p_name=indeks (dostęp: 2015.06.30).

5. World Health Organization. Chronic diseases and health promotion. http://www.who.int/chp/topics/rheumatic/en/ (dostęp: 2015.06.30).

6. Instytut Reumatologii. Narodowy Instytut Zdrowia Publicznego. Nasze zdrowie, nasze dolegliwości. Warszawa, 2002.

7. Woolf A. Pfleger B. Burden of major musculoskeletal conditions. Bulletin of the World Health Organization. 2003, 81(9): 646.

8. Reumatologia24.pl. http://www.reumatologia24.pl/reumatoidalne-zapalenie-stawow.htm (dostęp: 2015.07.10).

9. mp.pl. Reumatologia. http://reumatologia.mp.pl/choroby/63732,reumatoidalne-zapaleniestawow (dostęp: 2015.07.10).

10. eumusc.net. Musculoskeletal Health in Europe. http://www.eumusc.net/ workpackages_wp4.cfm (dostęp: 2015.07.17).

11. Owczarek A. Michalik R. Kotyla P. Skutki kliniczne, epidemiologiczne i ekonomiczne zmiany kryteriów klasyfikacyjnych wybranych chorób reumatycznych. Reumatologia, 2014, 52(2): 136-141.

12. eumusc.net. Musculoskeletal Health Key Statistics - Poland. 2011. http://www.eumusc.net/map/fs_pdf/FS_pl.pdf (dostęp: 2015.07.17). 